\title{
The Value of Intertextuality in Selvon's The Lonely Londoners and Naipaul's The Mimic Men
}

\author{
Imen Mzoughi \\ University of Tunis, Tunisia \\ $\&$
}

University of Shaqra, Faculty of Sciences and Arts of Sajer, Saudi Arabia

Email: ialmzoughi@su.edu.sa

Received: $2 / 3 / 2021$

Accepted: 5/8/2021

Published: 5/24/2021

\begin{abstract}
Studies on comparative literature have been fragmentary concentrating on one or two aspects of the thematic concerns of novels without emphasizing the concepts of divergent and convergent intertextuality. This paper aims to revisit Selvon's The Lonely Londoners re-reading it in dialogue with Naipaul's novel The Mimic Men. The selected novels are controversial. Criticism deployed on all fronts conveys the pluralities and oppositions that are in fact the novels' hallmarks. Yet, the aspects criticized attest to, and confirm, the authors' taking of the less trodden track. The comparative analysis within the scope of this paper will show that Naipaul's and Selvon's fictional representations of creolized Trinidadian and English societies highlight specific cultural and linguistic aspects and that intertextuality is either convergent or divergent. For instance, the structure of Naipaul's text takes as much from Caribbean orature and the wake of Caribbean plantation culture. However, Selvon's novel takes the form of flashbacks. Naipaul innovates and transforms Selvon's structure to generate a Caribbean context, par excellence. Traces of Selvon's style are present in Naipaul's corrosive voice of representing Caribbean identity. Naipaul brings to an apotheosis the creative force already illustrated in the remarkable works of Selvon. This paper aims to track these traces and foreground the idea that texts can speak to each other. More significantly, this paper assesses the main characters' fates to re-question the status of creoles, a status deliberately put between parentheses, denying them the right to voice their hybrid identities. Above all, the close textual reading of Galahad's and Singh's stories is meant to value the trope of intertextuality.
\end{abstract}

Keywords: appraisal, convergent intertextuality, creolized canon, divergent intertextuality, the lonely Londoners, and the mimic men

Cite as: Mzoughi, I. (2021). The Value of Intertextuality in Selvon's The Lonely Londoners and Naipaul's The Mimic Men. Arab World English Journal for Translation \& Literary Studies 5 (2) 39-48. DOI: http://dx.doi.org/10.24093/awejtls/vol5no2. 


\section{Introduction}

Caribbean literature is a unique study area. It is characterized by diversity. Likewise, the Caribbean archipelago is creolized since it is inhabited by creole subjects. Indeed, creoles' lineage brings the seemingly opposite white and black sides of their identities together: they were born into miscegenation, hybridity and creolization. The creole subject is physically, linguistically, socially and religiously a diverse human being. Employing literary writings, twentieth-century Caribbean writers have striven to reflect the multifaceted identity of creoles, making it a source of enrichment in the light of the magical connotations of the three-souled Caribbean (Amerindian, European and African). Indeed, the Caribbean has neither a boundary nor a center. Besides, the chequered history in the Caribbean has always crystallized the distinctiveness of literary discourses about Caribbean identity.

In this regard, Selvon and Naipaul explore the unbounded identities in the Caribbean. They invoke a collective identity and a heterogeneous self. The Caribbean subject can neither be contained nor appropriated. For Caribbean writers, the notions of Caribbean self and history reach beyond closure toward openness and diversity. As such, the Caribbean subject is no longer viewed as white or black, good or bad, but as a collection of possibilities. Born and raised in different islands of the Caribbean archipelago, Selvon and Naipaul have internalized the contradictions inherent to the Caribbean world. They have, indeed, multiple identities. As mentioned above, Caribbean writers are neither black nor white. Yet, they are hybrid. A brief biographical account of these writers seems to be compulsory.

Selvon was born in Trinidad. He is a Caribbean novelist based in Britain. Critic Salick (2001) avers that Selvon's merit lies in "entering the experience of the Trinidadian workers imaginatively, sympathetically and authentically" (p. 1). Besides, Selvon has chosen to embrace a cross-cultural life. Indeed, critic Salick (2001) reports that "living abroad for the best part of his life had broadened Selvon's horizons, but at the same time had surely deepened his love and appreciation for the land of his earth and upbringing" (p. 6). Salick (2001) further explains that "he was ever a down-to-earth man, who felt profound pleasure in the simple joys of Trinidad living: in the sweetness of a starch mango, in the taste of a katchourie, and in the song of apicoplat" (p. 6). Concerning the genre of his novels, critic Nasta (2002) explains that Selvon's novels are mainly peasant novels, middle-class novels, and immigrant novels. The choice of The Lonely Londoners is intentional. Indeed, the shibboleth of intertextuality is present in an immigrant novel, like, The Lonely Londoners.

Likewise, Naipaul is a Trinidadian writer stationed in Britain. He was educated in England. His novel The Mimic Men (1967) is a vivid account of the different influences shaping the Caribbean community and individuals. The book invokes a personal journey cast through the character of Singh. The latter is the archetype of a critical criollist. He seems to be assertive. Critic Nasta (2002), in her book entitled Home Truths, quotes Naipaul saying the following:

I can give you that historical bird's eye view. Most of us know the parents or grandparents we come from. But, we go back and back forever; we all of us go back to the very 
beginning; in our blood and bone and brain we carry the memories of thousands of beings" (p. 94).

The granted awards to Naipaul testify to his genius in adopting and adapting his narratives to accentuate the difference of the Caribbean subject.

\section{Literature Review}

Selvon's The Lonely Londoners (1956) and Naipaul's The Mimic Men (1967) constitute the analysis bases. The choice of these novels is deliberate because they illustrate the fact that the protagonists are hybrid: Galahad and Singh are creole subjects, that is, they are hybrid and of mixed descent. Their identification processes undergo remarkable shifts: they first identify themselves with blacks and perceive themselves as black Afro-Caribbean subjects; then, they come to terms with their creoleness. Singh and Galahad are thus creoles.

Both novels are allegorical accounts of the quest for identity. Quoting Lionnet (1989), these characters can be described as, "the stereotypical métis, the ones who embody the maledictions of miscegenation: the boundary crossers" (p. 176). They are "the third term, the excluded middle and the voice of the Antillean double bind" (p. 176). In many ways, they are the ultimate resolution to the contradictions of hybridity.

Selvon's The Lonely Londoners (1956) takes place in London. The story begins with Galahad, an Afro-Caribbean immigrant, who travels to London to pursue a better life. From the onset, he goes through an identity crisis. This is due to the ambivalent position taken by the protagonist toward both his ancestral homeland, that is, Africa, and the culture of his native island. The following quote said by Galahad's in The Lonely Londoners (1956) best illustrates his standpoint:

It ain't have no place in the world that exactly like a place where a lot of men get together to look for work and draw money from the Welfare State while they ain't working. Is a kind of place where hate and disgust and avarice and malice and sympathy and sorrow and pity all mix up. Is a place where everyone is your enemy and your friend. (p. 27)

Galahad's statement accentuates the binary of here/there and body/soul to deconstruct it. Blacks must be proud of their blackness. The latter must be perceived as a distinct racial category standing by reference to itself and not whiteness.

The Mimic Men (1967) is Naipaul's best seller. It mediates between the island of Isabella and London using flashbacks. The incipit evokes the funeral of Mr. Shylock, the owner of the house in London where Singh lives. Singh explains: "I had not been aware of death, had never seen those funeral processions which, rain or shine, had enlivened all our afternoons on the Caribbean island of Isabella" (p. 1). Death bewilders Singh in his exile in London. As the story unfolds, the readers learn that Singh has an in-between identity, which "seems to have occurred in parentheses" (p. 6). His eyes disturb Lieni, a Maltese boarder, who "could be recognized at a glance as an immigrant, Maltese, Italian, Cypriot" (p. 31). More importantly, "his dark, luxuriant and very 
soft hair might be a source of further disturbance" (p. 23). Besides, he does not disregard his origins: "I could not pretend even to myself to be part of the [London] community or to be putting down my roots" (p. 6). Singh explains:

It was up to me to choose my character, and I chose the character that was easiest and most attractive. I was the dandy, the extravagant colonial, indifferent to scholarship. (...) But, I let it be known that on my island my family were the bottlers of Coca-Cola. The fact impressed less than I had expected. But, the respect with which I was treated by boys from the island-to whom the fact was significant- was a help. (p. 23)

As one can easily infer, Singh's multiple origins do not hinder his cross-cultural connections with Londoners and Caribbeans.

A valuable starting-point for the discussion of the symbolic outcomes of being creole lies in setting up a conceptual framework through the work of King, et al. (1995), consisting of a series of possible shifts in Galahad's and Singh's identities that occur with migration, both at the personal and at the collective levels (p. 2). "Such realignments of identity," King, et al. (1995) explain, "may both precede migration (and in a sense, therefore, 'cause' it), and they may also occur as a result of movement to a new location" (p. 2). In this way, both Naipaul and Selvon conceptualize several overlapping multiple identities. In the selected novels, the subjects are constantly renegotiating their identities in the face of conflicts and compromises of hybridity. The act of migration often relates to Singh's and Galahad's calling into question the opposition between whiteness and blackness. This opposition forges their personalities and self-images. This is not to say that Singh and Galahad, as migrants, have necessarily fitted in the societal structure of every visited country.

Indeed, king, et al. (1995) further explain that "sociological and anthropological studies have often suggested that [creoles] may have effectively been lost to their home communities long before getting back home" (p. 2). "Not fitting in" can be considered as a principal characteristic of creoles. A thorny question that needs to be raised here is the following: Do Galahad's and Singh's creoleness lead to radical shifts in their identities or not? As creole subjects, Galahad's and Singh's identities are open to new influences. Many of these influences challenge their earlier selfperceptions and self-images. By being challenged, they change. Their identities are re-fashioned in a new light.

Shifts of identity are highly complex. These identitarian shifts are sometimes unstable. According to king, et al. (1995), identitarian shifts "have reversible elements built into them" (p. 3). King, et al. explain that these changes in identity "cannot be pinned down to a rigid linear continuum, for they represent the multiple and continually renegotiated outcomes of complex multifaceted phenomena operating both within individual biographies and for societies as a whole" (p. 3). As creole subjects, Galahad and Singh have lived in several countries and have moved between them swiftly. This results in ambivalence. As explained above, ambivalence marks their relationships in the past and in the present. They keep asking whether things were better 'then' or 'now.' They are also ambivalent toward the future. They feel that they do not belong. That is why, 
their identities are marked by ambiguity. Their creoleness entails open-ended relations with people, places and times. Throughout time, their identities change. The experiences through which they have gone progressively develop to influence the evolution of the seemingly opposite poles of their identities, ensuring their reconciliations.

\section{Objectives}

The main objectives of this paper are:

- To appraise the trope of intertextuality.

- To assess the concepts of divergent and convergent intertextuality through a close textual reading of the selected novels.

- To dismantle the opposition between whiteness and blackness.

- To highlight the contradictions underlying the intersection of colonialism and postcolonialism mainly through the ideological positions assumed by the characters and the discourses that reflect their actions.

\section{Research Methodology}

The selected novels are analyzed through the lenses of comparative literary theory. It is vital to assert that this paper uses Genette's concepts of divergent and convergent intertextuality. These concepts, indeed, confer cross-cultural characteristics on the compared novels paying no heed to national borders favoring thus a transnational analysis. The focus is on texts and not on the relationship between authors. Indeed, this paper examines the presence of references to other cultures, languages, and literary works. Certainly, the literary text can never be a total invention. It bears the traces of other texts. Genette's argument about comparative studies is thus essential. $\mathrm{He}$ asserts that the notion of establishing a basis for comparative literature lies in spotting references to 'foreign' words, expressions, or quotations. Following the steps of critic Brunel, critic Genette establishes the typology of borrowings. Dialogic in intention, this paper evokes allegiances to borrowings. Naipaul, for instance, borrows the form of Selvon's novel. According to critic O'Regan (2006), "The locus of Naipaul's intertextual divergence [from the Selvonian model] lies principally in its reuse as form per $s e$ " (p. 155). Its reuse form reveals a significant intertextual slippage. The two selected Caribbean writers draw out multifarious coiled stories and adopt carnivalized and creolized aesthetics to value the trope of intertextuality.

\section{Discussion and Analysis}

Early attempts at self-definition then take place in London for both Singh and Galahad. Henry Oliver is renamed 'Sir Galahad' by his host Moses, an Afro-Caribbean immigrant himself, who works and helps new Afro-Caribbeans in London. Selvon's novel (1956) manipulates key issues of ethnicity, politics, and place to foreground succinctly what Moses calls the "new, AfroCaribbean Londoners." For the following immigrants, namely, Moses, 'Sir Galahad,' Cap (a Nigerian immigrant), Bart (a lighter-skinned immigrant and a liar pretending to be a LatinAmerican to court an English girl), Big City (an immigrant from Trinidad), and Five past Twelve, who is:

Blacker than midnight," an immigrant from Barbados, the metropolis is "divide[d] in little worlds, and you stay in the world you belong to and you don't know anything about what happening in the other ones except what you read in the papers" (p. 74). 
Likewise, Singh's multiple identities help him comfort other characters' racial, cultural and social anxieties. Singh does not search for serenity. For Singh, disorder and complicated relationships are more immediate and more reassuring. He asserts that only "the panic of ceasing to feel myself as a whole person, the threat of other people's lives, the remembered private landscapes and the relationships" matter. Like Galahad, Singh yearns to escape from his native island. Yet, the memory of Isabella and its locals haunt him and prevent him from escaping: "the pale blue sky, green hills, brightly coloured houses, coconut trees and green sea" (p. 33). His marriage with Sandra is meant "to offer comfort and status to a woman who was denied these things in her country" (p. 44).

The two novels thus chronicle the challenges faced by their characters as they establish connections with mulattoes, African, Austrian, German, and French fellows. These Naipaulian and Selvonian perspectives on the realities of Caribbean subjects, which Ormerod (1985) describes as "attempts to acquire a sense of the continuous flow of time which lies dormant in the Caribbean landscape" (p. 36), deliberately establishes a specific discourse. This mirrors the contradictions that have marked the Caribbean archipelago. From this vantage point, and determined to put forward a discourse that will thoroughly express an identity rooted in difference, both Selvon and Naipaul merge standard languages and dialects. Their discourses, critic Murdoch (2001) explains, "ultimately write disjuncture into difference, ambiguity and anxiety into a dialectic that renegotiates a subtle subversion of authoritarian patriarchal codes" (p. 65). The polyphonous discourses of Naipaul and Selvon seem to represent Caribbeans as versatile different beings. Similarly, Singh's relational interaction with his fellows and the immigrants' interaction with different human beings shape the structures of the narratives studied within the scope of this paper. These interactions also delineate the ambivalence of Caribbean subjects.

Right from the start, the narratives' structures are appealing at two levels. First, the main themes of The Lonely Londoners and The Mimic Men, Murdoch (2001) contends, evoke the issue of alienation among creoles, and, more interestingly, the ambivalence of colonized subjects who must come to terms with London, the Caribbean and Africa (p. 67). According to Murdoch (2001), the personal dilemma of the Antillean caught between competing allegiances has long been a central narrative theme in Anglophone Caribbean literatures (67). Second, in The Lonely Londoners, it is the immigration of the "windrush generation" that gives Selvon's immigrants" situation its particular specificities. Immediately, in both novels, the readers identify themselves with protagonists, Murdoch (2001) explains, caught up in the double disjuncture that history imposed on Caribbean males. "[They are] split between the inability to recognize themselves as Caribbean subjects and the desire for subjective valorization which [they] hope the journey to London and the islands entail" (p. 67).

Creoleness is used by Naipaul and Selvon as a motif to explore the human condition in the Caribbean. As creoles, Galahad and Singh are dislocated and alienated. According to King, et al. (1995), alienation is also accompanied by motifs of indeterminacy and pluralism (p. 6). Indeed, king, el al. (1995) explain that alienation leads to the assertion of difference, "and towards the celebration of such differences as a vibrant and enhancing aspect of contemporary life" (p. 6).

Arab World English Journal for Translation \& Literary Studies 
Besides, their creoleness is closely connected with migration, dislocation and ensuing marginality. These are important markers.

Creoleness is also presented as a metaphor of death and rebirth. Creole subjects are, according to King, et al. (1995), doomed to experience migration and exile:

Around the turn of the century, it was a common practice to provide an 'American Wake' for Caribbean emigrants about to set off across the Atlantic - not only a reflection of impending individual loss, but also an indication of a whole community's attitude to migration and exile". (p. 6)

In foreign countries, creole subjects can also experience an awakening or a rebirth. Exile leads to the maturity of the creole subject. This idea is recurrent in Naipaul's and Selvon's narratives where exile grows to be an outward sign of want and desire related to a wider human yearning for maturity. The selected narratives cast the protagonists' choices between homecoming and leavetaking. They re-examine truths about life and death, too. These thematic polarities are explored via Galahad's and Singh's journeys which consist of both geographical relocations that call into question the significance of any concept related to belonging and of an inward journey into one's personality.

The narratives also explore the theme of return to the island, which is equated with the notion of starting again. To return is synonymous with 'to seek,' but also 'to lose.' Besides, the idea of return can be interpreted through temporal and spatial lenses. The protagonists' return to their 'own' past and place satisfy their longings. The change of their circumstances entails the alteration of borders and the transformation of their respective identities. While Singh's return to the island triggers unity within multiplicity triggered by memories of the past, Galahad's journey to London entails further distress and alienation. In Eliot's (1971) words, "in [Galahad's] beginning is [his] end" (p. 23). However, and perhaps, more interestingly, their journeys illustrate the utility of literature as a representation of the creole subject.

Through representing creoleness, Naipaul and Selvon give prominence to different levels of ambivalence, of plurality and of shifting identities. Also, the process of integration is represented as (in)complete. Indeed, the protagonists continually redefine perception of their identities at different stages of their lives. One may venture to say that exile intervenes in the process of renegotiating identity as a lasting force. The coming section teases out the divergences employed by Naipaul in his novel to differ from Selvon.

Naipaul changes the structure and the narrative technique. This arises from Naipaul's need to reflect certain cultural specificities of the Caribbean reality. These specificities lead to intertextual divergences between the two novels. The first intertextual divergence concerns temporal and spatial axes. The setting in The Mimic Men (1967) is funeral. In contrast, the journey is the main setting in The Lonely Londoners (1956). As such, Selvon's and Naipaul's novels diverge at the level of setting (time and space). This, critic O'Regan (2006) asserts, renders formal slippage inevitable in the Antillean hypertext" (p. 156). The time framework of Naipaul's novel 
is, for the most part, firmly rooted in the past. The narrator's most interior monologues react to and comment on past actions. The story in The Lonely Londoners (1956), however, is narrated from the perspective of West Indian immigrants. To put it differently, while Naipaul's novel moves backward through the technique of flashback, Selvon's text shuns action and suspends time.

The substitution of stasis in The Lonely Londoners by movement in The Mimic Men (1967) is praiseworthy. Critic O'Regan (2006) explains that it throws "the real-time dynamics of the hypertext into intertextual reverse in that it is consigned to a temporal and spatial limbo" (p. 156). Naipaul contextualizes the telling of his novel in the limbo of cremation. This is a Caribbean space, par excellence. Although the journey in The Lonely Londoners (1956) and the cremation in The Mimic Men (1967) are both transitional moments, Naipaul's treatment of the crossing from life to death differs from Selvon's in that it foregrounds profound realities in which the mourners are bound together highlighting the idea of shared humanism.

Naipaul's main interest lies in the polyphonic structure of Selvon's narrative. O'Regan (2006) argues that "the substantial differences in the structure of both novels convincingly point up the authors' designs to create distance with the hypotext in this respect" (p. 155). The entire text in The Mimic Men is, however, an interior monologue. Besides, the narrator in The Mimic Men speaks continuously binding the action as one story. In The Lonely Londoners (1956), the different immigrants, all speak. According to O'Regan (2006), this makes out of the text a story made up of plural and interconnected stories. "Each story possesses aesthetic and clearly didactic value" (p. 156).

In addition, one of the major divergences between text and intertext is the type of narration. In The Mimic Men (1967), all the free indirect discourses are in the first person pronoun. The main character is thus represented as the owner of his voice. In The Lonely Londoners (1967), however, some sections are narrated by first-person narrators, and others, by third-person narrators. This oscillation between first and third-person narration is due partly to Selvon's desire to problematize his characters' inner voices. Unlike Selvon, Naipaul adopts and adapts free indirect discourse to heighten a masculinist point of view. This yearning for the 'other' finds no parallel in Naipaul's novels. Naipaul's narrative partially resists all forms of racial mix. To put it in the words of O'Regan (2006), "in a general sense, the pessimistic discourse of a colonized subject in the postclonial world of the island of Isabella, being diametrically opposed to that of The Lonely Londoners, ensures significant intertextual divergence" (p. 186).

Although Naipaul sees creolization as a bless, he rejects it. Unlike Naipaul, Selvon appraises its benefits and urges Creoles to live according to its code. In this way, Galahad's memory of the island directs him toward an enabling present and a more promising future. In brief, the stories in both novels are most certainly unconventional. They are open-ended, polyphonic, and equivocal. They force the reader to participate in the re-construction of Caribbean history, and in the construction of an identity that looks back to past memories to reshape the present and refashion the future. 


\title{
Conclusion
}

The two narratives are about the crossing of creole selves through the motifs of migration, exile, funeral, and rebirths. Singh in The Mimic Men (1967) and Galahad in The Lonely Londoners (1956) make small, but confident steps toward more flexible and integrated selves. Above all, the intertextual link between Selvon and Naipaul must be valued. As demonstrated above, intertextuality occupies a prominent place and serves a critical discursive role. This paper thus reinforces the cross-cultural, literary and discursive agenda underpinning the intertextual line as it operates between the two novels by assessing Genette's concepts of divergent and convergent intertextuality.

Contrary to almost all the studies which only focus on themes, this study has attempted to take a different approach. Although it acknowledges the contributions of most of the critical approaches to the novels, this study implies that comparison must not be approached from the outside, so to speak, commitment to comparative literature must run deeper than comparing themes and characters. Both Naipaul and Selvon want to get inside their creole characters in order to understand and expose their basic drives, especially the conflict between two opposing realities, between two incompatible personalities, that is, whiteness and blackness. The reconciliation between whiteness and blackness can be possible.

One of the main findings of this paper is that both writers describe a different post/colonial creole subject, who has allegiances to pre-colonial, colonial and postcolonial worlds. What lies ahead Naipaul's and Selvon's calls for creoleness is the cultivation of a new kind of literature, a literature of reconnection. Their texts reconnect different characters from different worlds together. They shun closure and the claims of rigid racial and ethnic markers. Another finding of this paper is that Caribbean literature is in the process of writing and re-writing itself and it shall continue to do so. Caribbean literature celebrates the unbound identities of characters through the prism of intertextuality and dialogic discourses.

\begin{abstract}
About the Author
Imen Mzoughi is on secondment to the University of Shaqra, Saudi Arabia where she holds the position of assistant professor. She is the coordinator of the English department at the Faculty of Sciences and Arts of Sajer (2018-onward). She earned her Ph.D from the University of Manouba, Tunisia. Dr. Mzoughi has presented many papers in different international conferences on diverse thematic polarities. More importantly, she has eleven published articles, which figure out in indexed journals. More significantly, she has organized two main conferences on interdisciplinarity and objectivity. Also, she co-edited the volume on "Interdisciplinarity beyond the Divide," which appears in the first issue of Serial of Cross-cultural Issues ISLAI, Beja (March 2016). She was a fullbright scholar in Mississippi Valley State University, USA from 2008 to 2009. https://orcid.org/0000-0002-8598-1754
\end{abstract}

\section{References:}

Eliot, T. (1971). The Waste Land. In: Collected Poems 1909-1962. New York: Harcourt Brace Jovanovich. 
Genette, G. (1997). Palimpsests: Literature in the Second Degree. (Trans., G. Newman \& C. Doubinsky). Lincoln: University of Nebraska Press.

Lionnet, F. (1989). Autobiographical Voices: Race, Gender, Self-portraiture. Ithaca: Cornell University Press.

Murdoch, A. (2001). Creole identity in the Caribbean novel. University Press of Florida.

Naipaul, V.S. (1967). The Mimic Men. Vintage Books: New York.

Susheila, N. (1988). Critical Perspectives on Sam Selvon. Washington, D. C.: Three Continents Press.

Susheila, N. (2002). Home Truths: Fictions of the South-Asian Diaspora in Britain. London: Palgrave.

O’Regan, D. (2006). Postcolonial Echoes and Evocations. University of Michigan: Peter Lang.

Ormerod, B. (1985). An Introduction to the Caribbean Novel. London: Heinemann.

Russell, K., Connell, J., \& White, P. (1995). Writing Across Worlds: Literature and Migration. New York: Routledge.

Salick, R. (2001). The Novels of Samuel Selvon: A Critical Study. Greenwood Press: Westport, CT.

Selvon, S. (1956). The Lonely Londoners. New York: St. Martin's Press. 